\title{
EFFECT OF N, P AND CU FERTILIZATION ON ONION YIELD, QUALITY AND NUTRIENTS UPTAKE
}

El-Hadidi, E.M ${ }^{1}$; M.M. El-Shazly ${ }^{2}$ and Heba M.M. Hegazy ${ }^{3}$

1. Soil Sciences Department, Faculty of Agriculture, Mansoura University.

2. Soils, Water and Environment Research Institute, Agricultural Research Center, Giza.

3.Agricultural Engineer, Management of Agriculture in Mansoura, Ministry of Agriculture and Land Reclamation.

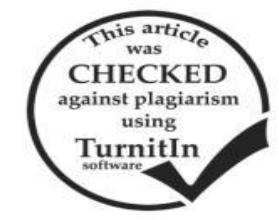

\begin{abstract}
A pot experiment was conducted at the Experimental Station Farm, Faculty of Agriculture, Mansoura University during the winter season of 2013/2014 to investigate the effect of phosphorus, nitrogen and copper fertilization on yield and nutrients uptake of onion (Allium cepa L.). The experiment was carried out in factorial experiment in complete randomized block design (CRBD) with three replications. The obtained results could be summarized as the following:

- Fertilizing onion plants with the highest level of phosphorus fertilizer $\left(100 \mathrm{~kg} \mathrm{P}_{2} \mathrm{O}_{5} \mathrm{fed}^{-1}\right)$ produced the highest values of all studied characters in the season.

- Application of the highest level of nitrogen fertilizer $\left(150 \mathrm{~kg} \mathrm{~N} \mathrm{fed}^{-1}\right)$ produced the highest values of yield, quality and nutrients uptake characters of onion in the season.

- Foliar spraying of onion plants with $\mathrm{Cu}$ at rate of $50 \mathrm{ppm}$ significantly surpassed control treatment (without spraying with $\mathrm{Cu}$ ) and produced the highest values of all studied characters in the season.

It can be concluded that fertilizing onion plants with $100 \mathrm{~kg} \mathrm{P}_{2} \mathrm{O}_{5} \mathrm{fed}^{-1}$ and $150 \mathrm{~kg} \mathrm{~N}^{-1}$ in addition to foliar spraying with 50 ppm $\mathrm{Cu}$ in the form of $\mathrm{CuSO}_{4}$ at three times in order to maximizing its yield, quality and nutrients uptake under the environmental conditions of Mansoura district, Dakahlia Governorate, Egypt.
\end{abstract}

Keywords: Onion, Nitrogen, Phosphorus, Copper, Foliar application, Yields, Quality, Nutrients uptake.

\section{NTRODUCTION}

Onion (Allium cepa L.) is amongst the main vegetable crops in Egypt for consumption processing and exportation .It is one of the most important sources for hard currency. Onion is highly valued herb possessing culinary (chopped, kippled or minced) and medicinal value. Onion contains many active compounds that appear to prevent of cardiovascular disease

Many agricultural practices judge the productivity of onion yield among these firstly chosen high yielding cultivars and using optimum level of mineral nitrogen and phosphorus fertilization as soil application as well as foliar application with copper as a micronutrient.

Phosphorus $(\mathrm{P})$ is one of the largest constraints to crop production in many semi-arid soils, owing to low native content and high $\mathrm{P}$ immobilization within the soil (Fairhust et al., 1999). Accordingly, P fertilization usually recommended in these soils. Phosphorus is essential for root development and when the availability is limited, plant growth usually reduced. In onions, P deficiencies reduce root and leaf growth, bulb size and yield and can delay maturation. In soils that are moderately low in $\mathrm{P}$, onion growth and yield can be enhanced by applied P. Onion is more susceptible to nutrient deficiencies than most crop plants because of their shallow and unbranched root system; hence they require and often respond well to addition of fertilizers (Brewester, 1994). Abdissa et al. (2011) found that phosphorus fertilizer levels $(0,10,20,30,40 \mathrm{~kg}$ $\mathrm{P}_{2} \mathrm{O}_{5} /$ ha) showed insignificant effects on most studied parameters. The lack of significant response in onion to $\mathrm{P}$ fertilization could be attributed to the presence of adequate amounts of available $\mathrm{P}(16.02 \mathrm{ppm})$ in the soil and hence $\mathrm{P}$ fertilization for onion production is not advisable. Moradi (2015) showed that phosphorus fertilizer as triple superphosphate levels $(0,100$ and 150 $\mathrm{kg} / \mathrm{ha}$ ) significantly improved the morphological properties of onion.

Nitrogen $(\mathrm{N})$ often referred to as the primary macronutrients because of the probability of plants being deficient in this nutrient and because of the large quantities taken up by plants from the soil relative to other essential nutrients (Marschner, 1995). Nitrogen is an essential element in all living systems and a major component of protein and chlorophyll. Under many agricultural settings, nitrogen is the limiting nutrient for high plant growth and yield (Marschner, 1995). It is required by plants in much greater amounts than all the other soil-supplied nutrients. Although nitrogen nutrient is an essential to increase bulb size and yield, onion growers believed that excessive nitrogen prevented proper ripening and resulted in bulbs with poor storage quality (Sheikh et al., 1987). Tekalign et al. (2012) found that nitrogen fertilization decreased bulb dry matter content by about $4 \%$ over the control. Nitrogen at rate of 115 or $138 \mathrm{~kg} \mathrm{~N} / \mathrm{ha}$ resulted in about $2.9 \%$ rotting of the bulbs. Nitrogen fertilization reduced bulb dry matter content and storability by enhancing sprouting and rotting percentage. Gessesew et al. (2015) revealed that application of $138 \mathrm{~kg} \mathrm{~N} / \mathrm{ha}$ was found the best treatment than others in relation to yield and yield components of onion. Moradi (2015) revealed that nitrogen fertilizer as urea levels $(0,150$ and $300 \mathrm{~kg} / \mathrm{ha}$ ) increased the fresh and dry weight, volume and bulb diameter of onion. The highest nitrate concentrations resulting from urea rate of $300 \mathrm{~kg} / \mathrm{ha}$. Weldemariam et al. (2015) revealed that nitrogen fertilizer rates $(0,46$, $69,92,115,138 \mathrm{~kg} / \mathrm{ha}$ ) showed significant effect on leaf number, plant maturity, plant height and leaf length. 
The longest plant height and leaf length was obtained from fertilizing with $138 \mathrm{~kg} \mathrm{~N} / \mathrm{ha}$. Overall, good growth performance of onion was obtained from fertilizing with $138 \mathrm{~kg} \mathrm{~N} / \mathrm{ha}$.

Copper $(\mathrm{Cu})$ is consider as essential micronutrients for plant growth and activation of many enzymes. A copper deficiency interferes with protein synthesis and causes a buildup of soluble nitrogen compounds. Normal plants contain 8 to 20 ppm copper and deficient plants usually contain less than $6 \mathrm{ppm}$. Copper deficiency in many plants shows up as wilting or lack of turgor and development of a bluish green tint before leaf tips become chlorotic and die. Onion bulbs show poor pigmentation because of copper deficiency. Alam et al. (2013) studied the effect of micronutrients ( $\mathrm{Zn}, \mathrm{B}, \mathrm{Mo}, \mathrm{Mn}, \mathrm{Cu}$ and $\mathrm{Cl}$ ) on growth and yield of onion. They found that foliar application of micronutrients significantly affected most of the yield contributing parameters of onion. Ballabh et al. (2013) studied the effects of foliar application of micronutrients $(\mathrm{Cu}, \mathrm{Zn}, \mathrm{B}, \mathrm{Fe}$, and $\mathrm{Mn}$ ) on growth, yield and quality of onion. They indicated that foliar feeding with micronutrients significantly improved vegetative growth parameters, total yield and quality contents in bulb tissues compared to control treatment. Ur Rahman et al. (2015) concluded that foliar application of micronutrients play an important role in the production of higher bulbs yield of onion.

Therefore, this study conducted to elucidate the effect of phosphorus, nitrogen and copper fertilization on yield and nutrients uptake of onion under the environmental conditions of Mansoura district, Dakahlia Governorate, Egypt.

\section{MATERIALS AND METHODS}

A pot experiment was conducted at the Experimental Station Farm, Faculty of Agriculture, Mansoura University during the winter season of $2013 / 2014$ to investigate the effect of phosphorus, nitrogen and copper fertilization on yield and nutrients uptake of onion (Allium cepa L.).

The experiment was carried out in factorial experiment in complete randomized block design (CRBD) with three replications. The experiment included eighteen treatments comprising, three phosphorus fertilizer levels, three nitrogen fertilizer levels and two levels of copper as foliar application. The first factor included three phosphorus fertilizer levels $(0$, 50 and $\left.100 \mathrm{~kg} \mathrm{P}_{2} \mathrm{O}_{5} \mathrm{fed}^{-1}\right)$. The second factor included three nitrogen fertilizer levels $\left(0,100\right.$ and $150 \mathrm{~kg} \mathrm{~N}$ fed $^{-}$ $\left.{ }^{1}\right)$. The third factor incorporated two levels of copper fertilizer as foliar application (0 and $50 \mathrm{ppm} \mathrm{Cu}$ ).

The experiment contained 25 plastic pots having a diameter of $25 \mathrm{~cm}$ and length of $35 \mathrm{~cm}$. The weigh of each pot is $10 \mathrm{~kg}$ represent the surface layer of $30 \mathrm{~cm}$ from station of faculty of Agriculture.

Data in table 1 show some soil physical and chemical properties.

Table 1: Some physical and chemical properties of the experimental soil before the cultivations of 2013/2014 season.

\begin{tabular}{|c|c|c|}
\hline Soil characteristics & & Values \\
\hline \multirow{5}{*}{ Particle size distribution } & Coarse sand (\%) & 2.8 \\
\hline & Fine sand $(\%)$ & 18.7 \\
\hline & Silt $(\%)$ & 35.6 \\
\hline & Clay $(\%)$ & 42.9 \\
\hline & Soil texture & Clay \\
\hline \multirow{6}{*}{$\begin{array}{l}\text { Some physical and chemical } \\
\text { properties }\end{array}$} & Field capacity $(\%)$ & 35.0 \\
\hline & Saturation $(\%)$ & 76.0 \\
\hline & Calcium carbonate $(\%)$ & 3.00 \\
\hline & O.M. $(\%)$ & 1.10 \\
\hline & $\mathrm{pH}(1: 2.5)$ & 8.30 \\
\hline & $\mathrm{EC}\left(\mathrm{dSm}^{-1}\right)$ soil paste ext. & 1.40 \\
\hline \multirow{4}{*}{ Soluble cations (meq. $\mathrm{L}^{-1}$ ) } & $\mathrm{Ca}^{2+}$ & 3.80 \\
\hline & $\mathrm{Mg}^{2+}$ & 0.80 \\
\hline & $\mathrm{Na}^{+}$ & 4.20 \\
\hline & $\mathrm{K}^{+}$ & 1.10 \\
\hline \multirow{4}{*}{ Soluble anions (meq. $\mathrm{L}^{-1}$ ) } & $\mathrm{CO}_{3}{ }^{2-}$ & - \\
\hline & $\mathrm{HCO}_{3}^{-}$ & 0.60 \\
\hline & $\mathrm{Cl}^{-}$ & 4.20 \\
\hline & $\mathrm{SO}_{4}^{2-}$ & 5.1 \\
\hline \multirow{2}{*}{ Available nutrients } & $\mathrm{P}$ ( $\mathrm{mg} \mathrm{kg}^{-1}$ soil $)$ & 7.91 \\
\hline & $\mathrm{K}\left(\mathrm{mg} \mathrm{kg}^{-1}\right.$ soil $)$ & 295 \\
\hline Total N & $\mathrm{N}\left(\mathrm{mg} \mathrm{kg}^{-1}\right.$ soil $)$ & 48.6 \\
\hline
\end{tabular}

Ten seeds of onion were sown on $24^{\text {th }}$ November 2013 at equal distance and depth. After 50 days from planting, onion plants were thinned to six uniform plants per pot. Soil moisture was kept at field capacity by watering each pot to the constant weight every 7 days.

The nitrogen fertilizer was added to soil of pots at three levels i.e. zero, $50 \mathrm{~kg} \mathrm{~N} \mathrm{fed}^{-1}\left(1.0 \mathrm{~g} \mathrm{pot}^{-1}\right)$ and 150 
$\mathrm{kg} \mathrm{N} \mathrm{fed}{ }^{-1}\left(1.49 \mathrm{~g} \mathrm{pot}^{-1}\right)$ in the form of ammonium sulphate $(20.5 \% \mathrm{~N})$ in three equal doses; after 21 days from planting, then 3 weeks after first dose, and 3 weeks after second dose. The phosphorus fertilizer was added to soil of pots at three rates zero, $50 \mathrm{~kg} \mathrm{P}_{2} \mathrm{O}_{5} \mathrm{fed}^{-1}(3.22$ $\mathrm{g} \mathrm{P}_{2} \mathrm{O}_{5}$ pot $\left.^{-1}\right)$ and $100 \mathrm{~kg} \mathrm{P}_{2} \mathrm{O}_{5}$ fed $^{-1}\left(6.44 \mathrm{~g} \mathrm{P}_{2} \mathrm{O}_{5}\right.$ pot $\left.^{-1}\right)$ in the form of calcium super phosphate $\left(15.5 \% \mathrm{P}_{2} \mathrm{O}_{5}\right)$ in one dose before planting. The potassium fertilizer was added to soil of pots as the recommended dose determined by the Ministry of Agriculture and Land Reclamation in the form of potassium sulphate $(48 \%$ $\mathrm{K}_{2} \mathrm{O}$ ) in two doses; after 15 days from planting, and 15 days later. Copper fertilizer as foliar application was done at two rates; zero and $50 \mathrm{ppm} \mathrm{Cu}$ in the form of $\mathrm{CuSO}_{4}$ at three times, after 21 days interval from planting. The foliar spraying was conducted by hand sprayer until saturation of leaves three times after 21,42 and 63 days from sowing. Tween-20 was used as a wetting agent at $0.02 \%$ concentration.

\section{Sampling dates}

\section{1) Yield components:}

After 90 days (harvest stage) from sowing of onion seeds, two plants were randomly taken from each treatment replicate to measure the following yield components:

- Plant height $(\mathrm{cm})$

- Average bulb fresh and dry weights (g) per plant.

- Bulb diameter $(\mathrm{cm})$.

- Neck diameter (cm).

2) Some soil chemical analysis:

- The values of EC were determined as mentioned by US Salinity Lab (1954).

- $\mathrm{pH}$ values were determined in soil suspension 1:2.5 (Jackson, 1967).

- Mechanical analysis of soil samples was done according to (Klute, 1986).

- Saturation percentage and field capacity were determined according to Klute (1986).

- Calcium carbonate was determined using Collin's calcimeter method (Jackson, 1967).

- Organic matter content was determined using Walkely's \& Black method (Jackson, 1967).

- Available N was determined as mentioned by Bremner (1965).

- Available P was determined according to Olsen and Sommers (1982).

- Available K was determined in extraction of soil sample as mentioned by Black (1965).

- Soluble cations and Anion, meg/L in saturated soil paste extract were determined according to Jackson (1967).

\section{Nutritional analysis of plant samples:}

The oven-dried onion plant sample was digested by using a sulfuric-perchloric acids mixture as described by Peterburgski (1968). The total N, P and $\mathrm{K}$ were determined using the following methods.
- Total nitrogen $(\%)$ was determined according to the method described by Pregle (1945), using microKjeldahl.

- Total phosphorus (\%) was determined colorimetrically using the chlorostannus reduce molybdo phosphoric blue colour method in sulphoric system as described by Jackson (1967).

- Potassium (\%) was determined using a flame photometer according to Black (1965).

- Crude protein percentage was calculated by determination of $\mathrm{N} \%$ by multiplication in 6.25 according to A.O.A.C. (2007).

- Estimation of heavy metals in digested plant sample solution was done using atomic absorption, Perkin elmer Model 5100 as described by Kumpulainen et al. (1983).

Data obtained were subjected to the statistical analysis according to the technique of analysis of variance (ANOVA) for the factorial experiment in complete randomized block design (CRBD) as reported by Gomez and Gomez (1984). Least significant of difference (LSD) method was used as described by Snedecor and Cochran (1980).

\section{RESULTS AND DISCUSSION}

\section{1- Effect of phosphorus fertilizer levels:}

Data presented in Tables 2, 3 and 4 illustrate that, the effect of phosphorus fertilizer levels on bulb fresh and dry weights, bulb diameter, neck diameter, plant height, nitrogen, phosphorus, potassium and protein percentages in onion bulbs, nitrogen, phosphorus, potassium and copper uptakes by onion plants, copper percentage, copper uptake and sulfur volatile oil percentage in onion bulbs after 90 days from sowing (at harvest stage) was significant in the season of this investigation. There were substantial differences in all studied characters among various studied phosphorus fertilizer levels i.e. 0,50 and $100 \mathrm{~kg} \mathrm{P}_{2} \mathrm{O}_{5} \mathrm{fed}^{-1}$ in the season. Since, fertilizing onion plants with the highest level of phosphorus fertilizer (100 kg $\left.\mathrm{P}_{2} \mathrm{O}_{5} \mathrm{fed}^{-1}\right)$ produced the highest values of the previously mentioned characters in growing season. On the other wise, control treatment (without phosphorus fertilization) gave the lowest values of these characters in the season. However, fertilizing onion plants with $50 \mathrm{~kg} \mathrm{P}_{2} \mathrm{O}_{5}$ fed $^{-1}$ came in the second rank after fertilizing with $100 \mathrm{~kg}$ $\mathrm{P}_{2} \mathrm{O}_{5} \mathrm{fed}^{-1}$ in the season. Such superiority in onion yield, quality and nutrients uptake because of increasing phosphorus fertilizer levels may be due to the function of phosphorus in building energy for metabolism of plant growth through cellular productions such as ATP and ADP from the early stages to the end of the plant's life (Marschner, 1995). Several researchers such as Abdissa et al. (2011) and Moradi (2015) reported similar results. 
Table 2: Bulb fresh and dry weights, bulb diameter, neck diameter and onion plant height after 90 days from sowing (at harvest stage) as affected by phosphorus, nitrogen and copper fertilization during 2013/2014 season.

\begin{tabular}{|c|c|c|c|c|c|}
\hline $\begin{array}{l}\text { Characters } \\
\text { Treatments } \\
\end{array}$ & $\begin{array}{c}\text { Bulb fresh } \\
\text { weight } \\
\text { (g) }\end{array}$ & $\begin{array}{l}\text { Bulb dry } \\
\text { weight } \\
\text { (g) }\end{array}$ & $\begin{array}{c}\text { Bulb } \\
\text { diameter } \\
(\mathbf{c m}) \\
\end{array}$ & $\begin{array}{c}\text { Neck } \\
\text { diameter } \\
(\mathbf{c m}) \\
\end{array}$ & $\begin{array}{c}\text { Plant height } \\
(\mathrm{cm})\end{array}$ \\
\hline \multicolumn{6}{|c|}{ A- Phosphorus fertilizer levels: } \\
\hline $0 \mathrm{~kg} \mathrm{P}_{2} \mathrm{O}_{5} \mathrm{fed}^{-1}$ & 70.52 & 9.53 & 5.41 & 1.91 & 69.65 \\
\hline $50 \mathrm{~kg} \mathrm{P}_{2} \mathrm{O}_{5} \mathrm{fed}^{-1}$ & 72.27 & 9.86 & 5.97 & 2.67 & 71.67 \\
\hline $100 \mathrm{~kg} \mathrm{P}_{2} \mathrm{O}_{5}$ fed $^{-1}$ & 72.45 & 9.88 & 6.04 & 2.77 & 72.03 \\
\hline F. test & $*$ & $*$ & $*$ & $*$ & $*$ \\
\hline LSD at $5 \%$ & 0.12 & 0.03 & 0.06 & 0.09 & 0.58 \\
\hline \multicolumn{6}{|c|}{ B- Nitrogen fertilizer levels: } \\
\hline $0 \mathrm{~kg} \mathrm{~N} \mathrm{fed}^{-1}$ & 69.62 & 9.29 & 5.08 & 1.75 & 70.23 \\
\hline $100 \mathrm{~kg} \mathrm{~N} \mathrm{fed}^{-1}$ & 72.38 & 9.93 & 6.07 & 2.74 & 71.22 \\
\hline $150 \mathrm{~kg} \mathrm{~N} \mathrm{fed}^{-1}$ & 73.23 & 10.06 & 6.27 & 2.87 & 71.90 \\
\hline F. test & $*$ & $*$ & $*$ & $*$ & $*$ \\
\hline LSD at $5 \%$ & 0.07 & 0.04 & 0.08 & 0.08 & 0.67 \\
\hline \multicolumn{6}{|c|}{ C-Copper fertilizer levels: } \\
\hline Without & 71.16 & 10.09 & 5.62 & 2.28 & 69.19 \\
\hline $50 \mathrm{ppm} \mathrm{Cu}$ & 72.34 & 10.20 & 5.99 & 2.62 & 73.04 \\
\hline F. test & $*$ & $*$ & $*$ & $*$ & $*$ \\
\hline \multicolumn{6}{|l|}{ D- Interactions: } \\
\hline $\mathrm{A} \times \mathrm{B}$ & $*$ & $*$ & $*$ & $*$ & NS \\
\hline $\mathrm{A} \times \mathrm{C}$ & $*$ & $*$ & $*$ & $*$ & NS \\
\hline $\mathrm{B} \times \mathrm{C}$ & $*$ & $*$ & NS & NS & NS \\
\hline $\mathrm{A} \times \mathrm{B} \times \mathrm{C}$ & $*$ & NS & NS & NS & NS \\
\hline
\end{tabular}

Table3:Nitrogen, phosphorus, potassium and protein percentages in onion bulbs after 90 days from sowing (at harvest stage) as affected by phosphorus, nitrogen and copper fertilization during 2013/2014 season. Characters

\begin{tabular}{|c|c|c|c|c|}
\hline \multicolumn{4}{|l|}{ Treatments } & Protein (\%) \\
\hline \multicolumn{5}{|c|}{ A- Phosphorus fertilizer levels: } \\
\hline $0 \mathrm{~kg} \mathrm{P}_{2} \mathrm{O}_{5} \mathrm{fed}^{-1}$ & 2.33 & 0.320 & 1.88 & 14.57 \\
\hline $50 \mathrm{~kg} \mathrm{P}_{2} \mathrm{O}_{5}$ fed $^{-1}$ & 2.60 & 0.354 & 2.22 & 16.29 \\
\hline $100 \mathrm{~kg} \mathrm{P}_{2} \mathrm{O}_{5} \mathrm{fed}^{-1}$ & 2.64 & 0.354 & 2.41 & 16.50 \\
\hline F. test & $*$ & $*$ & $*$ & $*$ \\
\hline LSD at $5 \%$ & 0.03 & 0.004 & 0.02 & 0.21 \\
\hline \multicolumn{5}{|c|}{ B- Nitrogen fertilizer levels: } \\
\hline $0 \mathrm{~kg} \mathrm{~N} \mathrm{fed}^{-1}$ & 2.13 & 0.302 & 1.87 & 13.32 \\
\hline $100 \mathrm{~kg} \mathrm{~N} \mathrm{fed}^{-1}$ & 2.67 & 0.358 & 2.25 & 16.74 \\
\hline $150 \mathrm{~kg} \mathrm{~N} \mathrm{fed}^{-1}$ & 2.77 & 0.368 & 2.40 & 17.31 \\
\hline F. test & $*$ & $*$ & $*$ & $*$ \\
\hline LSD at $5 \%$ & 0.03 & 0.003 & 0.01 & 0.20 \\
\hline \multicolumn{5}{|c|}{ C-Copper fertilizer levels: } \\
\hline Without & 2.43 & 0.333 & 2.12 & 15.20 \\
\hline $50 \mathrm{ppm} \mathrm{Cu}$ & 2.62 & 0.352 & 2.22 & 16.37 \\
\hline F. test & $*$ & $*$ & $*$ & $*$ \\
\hline \multicolumn{5}{|l|}{ D-Interactions: } \\
\hline $\mathrm{A} \times \mathrm{B}$ & $*$ & $*$ & $*$ & $*$ \\
\hline $\mathrm{A} \times \mathrm{C}$ & $*$ & $*$ & $*$ & $*$ \\
\hline $\mathrm{B} \times \mathrm{C}$ & $*$ & $*$ & $*$ & $*$ \\
\hline $\mathrm{A} \times \mathrm{B} \times \mathrm{C}$ & $*$ & $*$ & $*$ & $*$ \\
\hline
\end{tabular}

\section{2- Effect of nitrogen fertilizer levels:}

Data in Tables 2, 3 and 4 show that the effect of nitrogen fertilizer levels on all studied characters i.e. bulb fresh and dry weights, bulb diameter, neck diameter, plant height, nitrogen, phosphorus, potassium and protein percentages in onion bulbs, nitrogen, phosphorus, potassium and copper uptakes by onion plants, copper percentage, copper uptake and sulfur volatile oil percentage in onion bulbs after 90 days from sowing (at harvest stage) was significant in the season. It can be stated that all studied yield, quality and nutrients uptake characters of onion significantly 
increased as a result of increasing nitrogen fertilizer levels from 0 to 100 and $150 \mathrm{~kg} \mathrm{~N}^{-1}$ and the differences among them were obvious in the season. Application of the highest level of nitrogen fertilizer $\left(150 \mathrm{~kg} \mathrm{~N} \mathrm{fed}^{-1}\right)$ produced the highest values of yield, quality and nutrients uptake characters of onion in the season. Fertilizing onion plants with $100 \mathrm{~kg} \mathrm{~N}^{-1}$ came in the second rank after fertilizing with $150 \mathrm{~kg} \mathrm{~N}$ $\mathrm{fed}^{-1}$ with respect to these characters in the season. The lowest values of yield, quality and nutrients uptake characters of onion were resulted from control treatment (without nitrogen fertilization) in the season. These increases in yield, quality and nutrients uptake characters of onion as a result of increasing nitrogen fertilizer level up to $150 \mathrm{~kg} \mathrm{~N}$ fed $^{-1}$ can be ascribed to the role of the essential role of nitrogen fertilizer in formation of proteins, protoplasm and chlorophyll, consequently increases cell size, leaf area, photosynthetic activity and growth characters accordingly increased yield attributes, quality and nutrients uptake of onion. Similar results were in coincidence with those stated by Tekalign et al. (2012), Gessesew et al. (2015), Moradi (2015) and Weldemariam et al. (2015).

Table 4: Nitrogen, phosphorus, potassium and copper uptakes by onion plants, copper percentage, copper uptake and sulfur volatile oil percentage in onion bulbs after 90 days from sowing (at harvest stage) as affected by phosphorus, nitrogen and copper fertilization during 2013/2014 season.

\begin{tabular}{|c|c|c|c|c|c|c|}
\hline Characters & $\begin{array}{c}\text { N-uptake } \\
\left(\text { mg plant }^{-1}\right)\end{array}$ & $\begin{array}{c}\text { P-uptake } \\
\left(\mathrm{mg} \mathrm{plant}^{-1}\right)\end{array}$ & $\begin{array}{c}\text { K-uptake } \\
\left(\text { mg plant }^{-1}\right)\end{array}$ & $\mathrm{Cu}(\mathbf{p p m})$ & $\begin{array}{c}\text { Cu-uptake } \\
\left(\text { mg plant }^{-1}\right)\end{array}$ & $\begin{array}{c}\text { Sulfur } \\
\text { volatile oil } \\
(\%)\end{array}$ \\
\hline \multicolumn{7}{|l|}{ A- Phosphorus fertilizer levels: } \\
\hline $0 \mathrm{~kg} \mathrm{P}_{2} \mathrm{O}_{5}$ fed $^{-1}$ & 223.0 & 30.54 & 180.2 & 1.11 & 0.011 & 1.31 \\
\hline $50 \mathrm{~kg} \mathrm{P}_{2} \mathrm{O}_{5} \mathrm{fed}^{-1}$ & 258.5 & 35.07 & 221.3 & 1.50 & 0.015 & 1.61 \\
\hline $100 \mathrm{~kg} \mathrm{P}_{2} \mathrm{O}_{5} \mathrm{fed}^{-1}$ & 262.2 & 35.14 & 239.7 & 1.61 & 0.016 & 1.71 \\
\hline F. test & $*$ & $*$ & $*$ & $*$ & $*$ & $*$ \\
\hline LSD at $5 \%$ & 3.2 & 0.36 & 2.4 & 0.03 & 0.001 & 0.01 \\
\hline \multicolumn{7}{|l|}{ B- Nitrogen fertilizer levels: } \\
\hline $0 \mathrm{~kg} \mathrm{~N} \mathrm{fed}^{-1}$ & 198.2 & 28.12 & 173.9 & 1.24 & 0.012 & 1.41 \\
\hline $100 \mathrm{~kg} \mathrm{~N} \mathrm{fed}^{-1}$ & 266.3 & 35.56 & 224.3 & 1.41 & 0.014 & 1.53 \\
\hline $150 \mathrm{~kg} \mathrm{~N} \mathrm{fed}^{-1}$ & 279.3 & 37.07 & 243.0 & 1.58 & 0.016 & 1.69 \\
\hline F. test & $*$ & $*$ & $*$ & $*$ & $*$ & $*$ \\
\hline LSD at $5 \%$ & 3.1 & 0.34 & 2.7 & 0.03 & 0.001 & 0.01 \\
\hline \multicolumn{7}{|l|}{ C-Copper fertilizer levels: } \\
\hline Without & 236.3 & 32.30 & 206.5 & 0.66 & 0.007 & 1.15 \\
\hline $50 \mathrm{ppm} \mathrm{Cu}$ & 259.6 & 34.86 & 221.0 & 2.15 & 0.021 & 1.94 \\
\hline F. test & $*$ & $*$ & $*$ & $*$ & $*$ & $*$ \\
\hline \multicolumn{7}{|l|}{ D- Interactions: } \\
\hline $\mathrm{A} \times \mathrm{B}$ & $*$ & $*$ & $*$ & $*$ & $*$ & $*$ \\
\hline $\mathrm{A} \times \mathrm{C}$ & $*$ & $*$ & $*$ & $*$ & $*$ & $*$ \\
\hline $\mathrm{B} \times \mathrm{C}$ & $*$ & $*$ & $*$ & $*$ & $*$ & $*$ \\
\hline $\mathrm{A} \times \mathrm{B} \times \mathrm{C}$ & $*$ & $*$ & $*$ & $*$ & $*$ & $*$ \\
\hline
\end{tabular}

\section{3- Effect of copper fertilizer levels:}

The effect of copper fertilizer levels as foliar application on onion yield, quality and nutrients uptake i.e. bulb fresh and dry weights, bulb diameter, neck diameter, plant height, nitrogen, phosphorus, potassium and protein percentages in onion bulbs, nitrogen, phosphorus, potassium and copper uptakes by onion plants, copper percentage, copper uptake and sulfur volatile oil percentage in onion bulbs after 90 days from sowing (at harvest stage) was significant in the season as shown in Tables 2, 3 and 4. From obtained results, it could be recommend that foliar spraying onion plants with $\mathrm{Cu}$ at the rate of $50 \mathrm{ppm}$ which significantly surpassed control treatment (without spraying with $\mathrm{Cu}$ ) and produced the highest values of all studied characters in the season under the environmental conditions of this study. The increases in onion yield, quality and nutrients uptake by foliar application with $\mathrm{Cu}$ at rate of $50 \mathrm{ppm}$ may be due to the role of $\mathrm{Cu}$ as essential micronutrients for plant growth and activation of many enzymes.
Confirming this conclusion by Alam et al. (2013), Ballabh et al. (2013) and Ur Rahman et al. (2015).

\section{CONCLUSION}

It can be concluded that fertilizing onion plants with $100 \mathrm{~kg} \mathrm{P}_{2} \mathrm{O}_{5} \mathrm{fed}^{-1}$ and $150 \mathrm{~kg} \mathrm{~N}^{-1} \mathrm{fed}^{-1}$ in addition to foliar spraying with $50 \mathrm{ppm} \mathrm{Cu}$ in the form of $\mathrm{CuSO}_{4}$ at three times in order to maximizing its yield, quality and nutrients uptake under the environmental conditions of Mansoura district, Dakahlia Governorate, Egypt.

\section{REFERENCES}

A.O.A.C. (2007). Official Methods of Analysis. $18^{\text {th }} \mathrm{Ed}$. Association of Official Analytical Chemists, Inc., Gaithersburg, MD, Method 04.

Abdissa, Y. ; T. Tekalign and L. M. Pant (2011). Growth, bulb yield and quality of onion (Allium cepa L.) as influenced by nitrogen and phosphorus fertilization on vertisol. I- Growth attribute biomass production and bulb yield. Arican J. of Agric. Res., 6(14): 3252-3258. 
Alam, M.N. ; M.J. Abedin and M.A.K. Azad (2013). Effect of micronutrients on growth and yield of onion under calcareous soil environment. Intern. Res. J. of Plant Sci., 1(3): 56-61.

Ballabh, K. ; D.K. Rana and S.S. Rawat (2013). Effects of foliar application of micronutrients on growth, yield and quality of onion. Indian J. of Hort., 70(2): $260-265$.

Black, C. A. (1965). Methods of Soil Analysis. Amer.Soc.Agron.Inc.Pub., Madison,Wisconsin,USA.

Bremner,J.M.(1965).Total nitrogen.Inc.Black etal. (ed.) Methods of soilAnalysis.part2.Agronomy9:11491178.Am.Soc.Agron.,Inc.,Madison,Wisconsin,U SA.

Brewester, J.L. (1994). Onions and other vegetable Alliums.CABInternational,Wallingford,UK,p. 36.

Fairhust, T. ; R. Lefroy ; E. Mutert and N. Batijes (1999). The importance, distribution and causes of phosphorus deficiency as a constraint to crop production in the tropics. Agrofor. Forum, 9: 2-8.

Gessesew, W.S. ; K. Woldetsadik and W. Mohammed (2015). Effect of nitrogen fertilizer rates and intra-row spacing on yield and yield components of onion (Allium cepa L. Var. cepa) under irrigation in Gode, South-Eastern Ethiopia. Int. J. Plant Breeding Crop Sci., 2(2): 46-54.

Gomez, K.A. and A.A. Gomez (1984). Statistical Procedures for Agricultural Research. 2nd Edn., Jhon Wiley and Sons Inc., New York,pp: 95-109.

Jackson, M. L. (1967). "Soil Chemical Analysis" Prentica Hall Inc, Engleweed Cliffs, N. J.

Klute,A. (1986). Water retension : laboratory methods. In: A. Koute (ed.)Methods of Soil Analysis, part $1,2^{\text {nd }}$ ed. Agron. Monogr. 9, A S A, Madison, USA,PP635-660.

Kumpulainen,I;A.M.Raittila;I.Lehto and P.Koiristoinen (1983).Electro thermal Atomic Absorption spectrophotometric determination of heavy metals in foods and diets.J. Associ. Anal.Chem; 66:1129-1135.

Marschner, H. (1995). Mineral nutrition of higher plants. Academic press San Diego, USA.
Moradi, S. (2015). Impact of sheep manure, urea and triple superphosphate on onions morphological properties. Intern. J. of Farming and Allied Sci., 4 (2): 167-170.

Olsen,S.R.and L.E.Sommers(1982).Phosphorus.In:A. L. Pages;R.H.Miller and D.R.Keeney (ed.) Methods of Soil Analysis .Part 2 ( $2^{\text {nd }}$ Ed.) Chemical and Microbiological Properties.ASAA,Inc.and SSSA. Inc., Publisher,Madison,Wisconsin,USA.

Peterburgski, A.V. (1968) "Hand Book of Agronomic Chemistry" Kolop Publishing House, Moscow (in Russian). pp. 29-86.

Pregle,E. (1945).Quantitative organic micro-analysis. $4^{\text {th }}$ Ed.J.Chudrial,London.

Sheikh, M.A; A.H. Ansari;S.M. Qayyum, M.B. Qayyum and S.A. Hussain (1987). Technical report on effect of nitrogen doses on the growth and crop yield of onion. Pakistan Agriculture, 9: 35-40.

Snedecor, G. W. and W. G. Cochran (1980). Statistical methods. $7^{\text {th }}$ edition, Iowa State University Press, Ames, Iowa.

Tekalign, T. ; Y. Abdissa and L.M. Pant (2012). Growth, bulb yield and quality of onion (Allium cepa L.) as influenced by nitrogen and phosphorus fertilization on vertisol. II: Bulb quality and storability. African J. of Agric. Res., 7 (45): 5980-5985.

Ur Rahman, I. ; F. Afzal ; Z. Iqbal ; F. Ijaz and N. Ali (2015). Influence of foliar nutrients application on growth and yield of onion grown in nutrient deficient soil. Bangladesh J. Bot. 44(4): 613-619.

US Salinity Lab (1954).Diagnosis and Improvement of Saline and Alkali Soils. USA.Agric.Handbook No.60.

Weldemariam, S.G. ; K. Woldetsadik and W. Mohammed (2015). Growth parameters of onion (Allium cepa L. var. Cepa) as affected by nitrogen fertilizer rates and intra-row spacing under irrigation in Gode, South-Eastern Ethiopia. Agriculture, Forestry and Fisheries, 4(6): 239245.
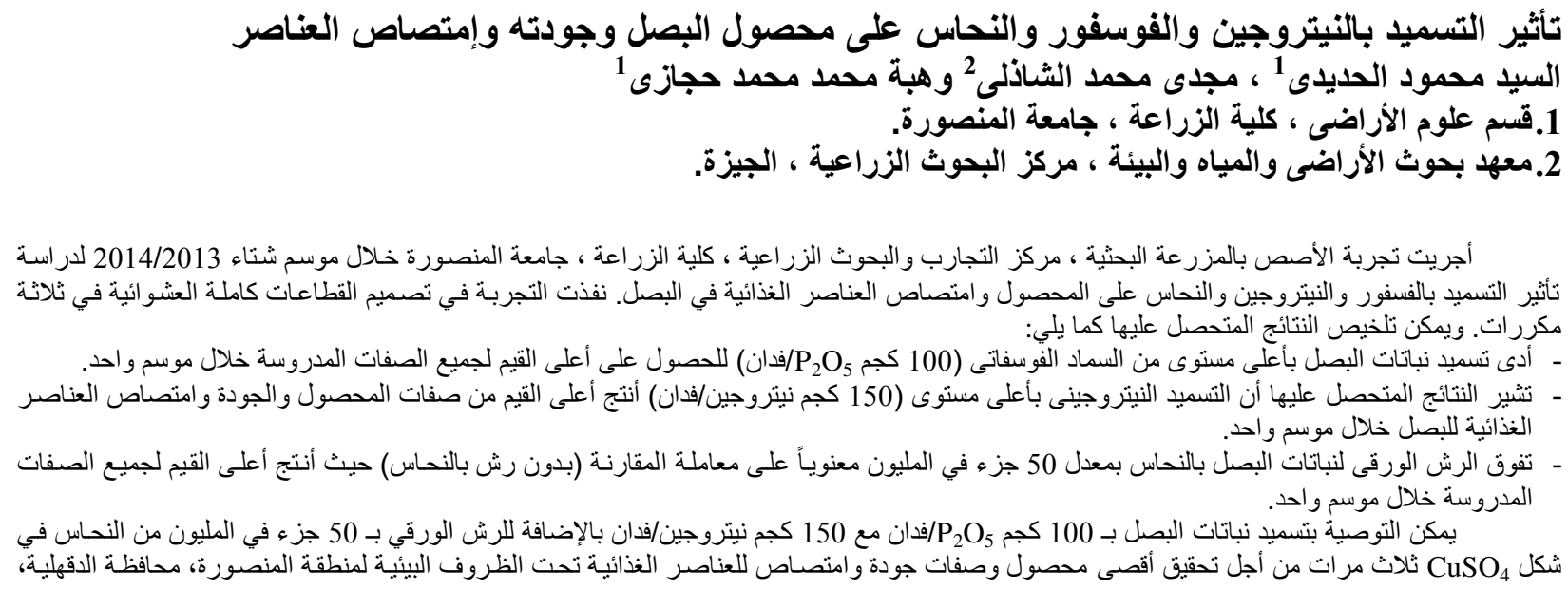